\title{
Exploring the possibilities for implementation of the Dutch Biodiversity Monitor for farming in the CAP after 2022
}

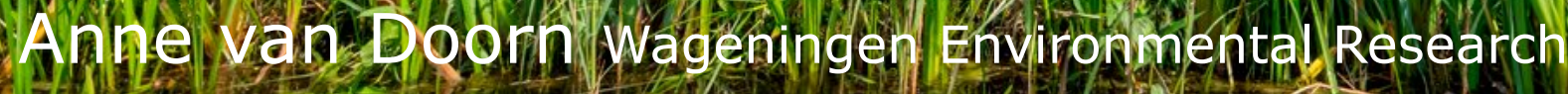
Roel Jongeneel Wageningen Economic Research 


\section{Abstract}

A Dutch Biodiversity Monitor for farming (DBM) is currently being developed. The DBM measures the contribution that farmers make to biodiversity on the farm and beyond through Key Performance Indicators (KPIs). One of the major goals of the DBM is ultimately to reward farmers for their performance on biodiversity. This can be done by multiple agents such as value chain partners, regional governments and possibly also through payments of the Common Agricultural Policy (CAP). This document explores whether and how the DBM for dairy and arable farming can be applied as an instrument in the CAP after 2022. From the assessment it can concluded that the DBM has potential to be used in the CAP as it combines an integrated approach towards biodiversity, environment and climate with a relatively simple instrument that allows for performance-based payments. The most favourable option is to use the DBM in the eco-schemes: farmers that use the DBM and score above certain thresholds, are considered to be 'green by definition' and receive a green top-up. However, before the DBM can be applied in the CAP, a couple of issues have to be dealt with: firstly streamlining KPIs with the environmental baseline, ensuring that no overlap occurs with $2^{\text {nd }}$ pillar payments, and secondly obtaining better insight into the costs incurred and income foregone for farming activities linked to KPIs to underpin the level of payments for the eco-schemes. We recommend further study of the application of the DBM in the CAP in a pilot through learning by doing.

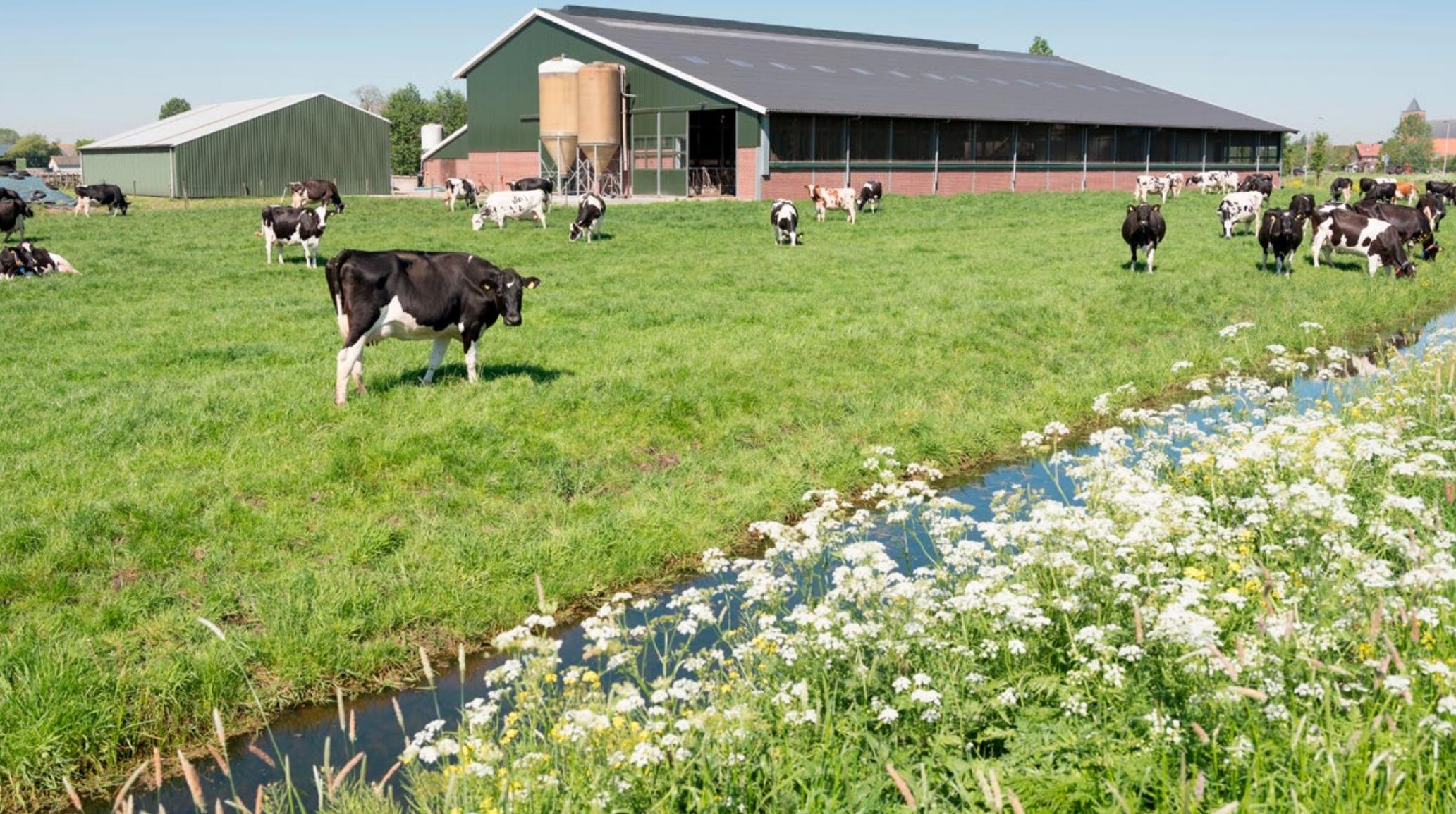




\section{Content}

Abstract

1 Introduction

1.1 Research questions

2 CAP: current proposals, Member State choices \& legislative framework

2.1 Proposals for the reform of the CAP after 2022: objectives, process \& instruments

2.2 Summary of the draft SWOT for environmental objectives

2.3 Choices for Member States

2.3.1 Enhanced conditionality

2.3.2 The eco-schemes

2.4 Relevant elements of the legislative framework of the CAP, including WTO and state aid rules?

2.5 Current position of the Netherlands

3 The Dutch Biodiversity Monitor

3.1 Background

3.2 The Dutch Biodiversity Monitor for dairy farms

3.3 The Dutch Biodiversity Monitor for arable farms

4 Possibilities for implementation of the biodiversity monitor within the CAP

4.1 Serve CAP objectives \& national strategic plan

4.2 Fit into CAP green-blue architecture

4.3 No payments for activities below the environmental baseline and no double funding

4.4 Payments should not cause trade distortion and should be accountable

4.5 Performance based and avoiding green washing

4.6 Practicalities

5 Concluding remarks 


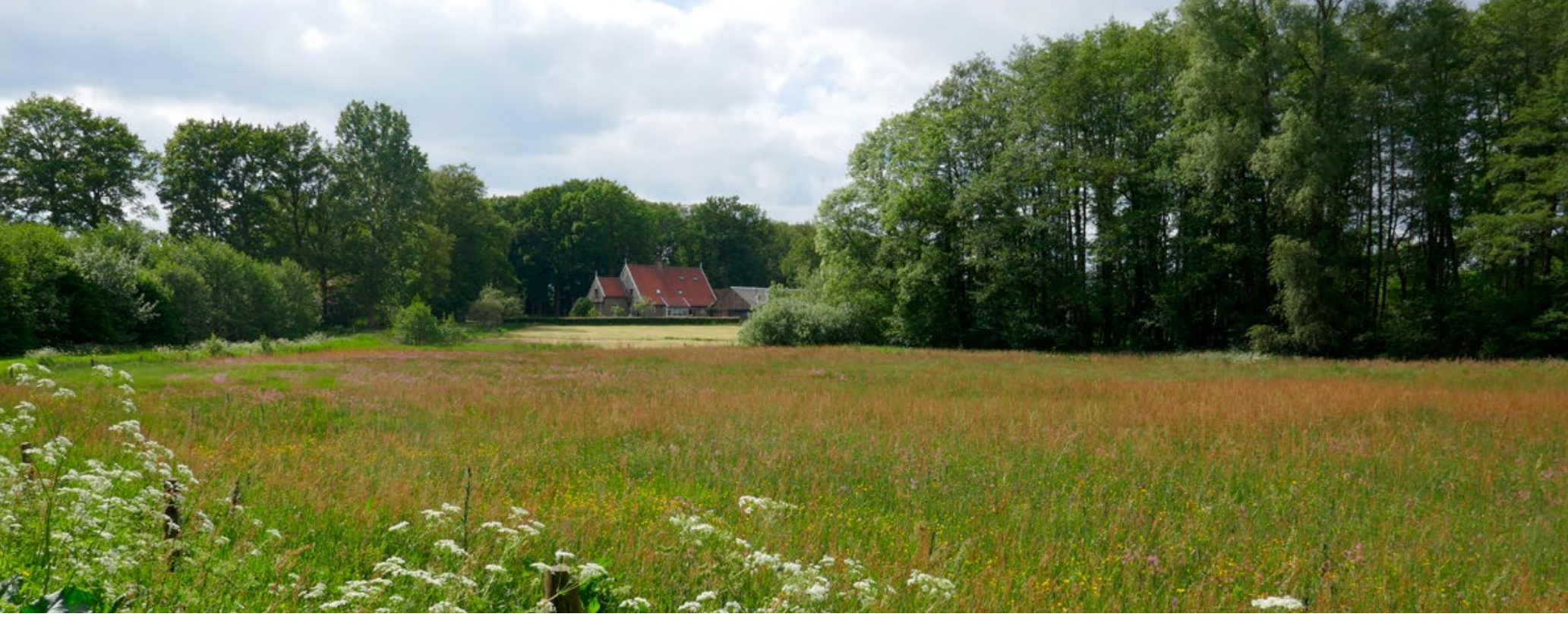

1 Introduction

The European common agricultural policy (CAP) is an important driving factor for Europe's farmland. The next reform of the CAP is currently in preparation and a new CAP is expected to start in 2023. Member States are requested to implement the new CAP through a National Strategic Plan serving nine CAP objectives - across environmental, economic and social pillars. Additionally there is a $10^{\text {th }}$ overarching objective for modernising the policy. The three environmental objectives are climate action, environmental care, and preserving landscapes and biodiversity. Direct income support will be - partly substituted for performance-based payments contributing to these environmental objectives.

The WWF-NL aims at a CAP that stimulates the transition to sustainable agriculture in resilient landscapes and contributes to the restoration of biodiversity. Recently, WWF-NL developed together with FrieslandCampina, Sustainable Dairy Chain (Duurzame Zuivelketen) and the Rabobank a Biodiversity Monitor for dairy farming. A Biodiversity Monitor for arable farming is currently being developed (Branche Organisation Arable Farming, Rabobank, Province of Groningen and WWF-NL). The Dutch Biodiversity Monitor (DBM) measures the contribution that farmers make to biodiversity on the farm and beyond through Key Performance Indicators (KPIs).
The KPIs constitute an integrated set which collectively reflect biodiversity performance. This means a) the biodiversity monitor not only targets biodiversity goals, but also contributes to soil, climate, air and landscape objectives and $b$ ) that KPIs are never applied individually; they have to be used as a set and balance one another.

One of the major goals of the DBM is ultimately to reward farmers for their performance on biodiversity. This can be done by multiple agents such as value chain partners, regional governments and possibly also the EU through CAP payments. In this way stacked financing of biodiversity and ecosystem services is realised. Therefore WWF-NL-NL wants to explore whether and how the Dutch Biodiversity Monitor (DBM) for dairy and arable farming can be applied as an instrument in the implementation of the CAP after 2022. A key question is whether the DBM could be used to link CAP payments to the performance for biodiversity?

This kind of linkage is also in line with the advice of the Council for the Environment and Infrastructure (Rli 2019). Their advice is to create synergy with private sustainability schemes. The question is how this can be achieved and this paper contributes to the discussion as it explores the possibilities of using the DBM as an instrument in the CAP post 2022 for performance-based payments. 


\subsection{Research questions}

To explore to what extent the DBM can be applied in the CAP, especially to contribute to stacked financing of biodiversity and ecosystem services through CAP payments, the main elements of the CAP are first discussed based on the following questions:

1 What is the content of the European Commission's proposal for a new CAP? Specifically with regard to green architecture.

2 To underpin the National Strategic Plan, Member States carry out a SWOT analysis on the nine CAP objectives for their territory. What are the most important agri-environmental issues for the Netherlands?

3 What are the choices that Member States have when implementing the CAP with regard to: (Enhanced) conditionality ( $1^{\text {st }}$ pillar), Eco-schemes ( $1^{\text {st }}$ pillar $)$, agri-environmental climate measures ( $2^{\text {nd }}$ pillar)? The focus will be on management measures, that concerns the largest share of the CAP budget, and not on subsequent investments.
Next, in the light of the CAP context the following question is considered:

4 What are the possibilities and what is the added value of using the DBM in the new CAP? Both Pillar 1 (enhanced conditionality and eco-schemes) and Pillar 2 (agro-environmental climate measures) are discussed with regard to the following aspects:

- the current issues for biodiversity, environment and climate.

- the use of performance-based payments and how they can be used to continue to stimulate the movement towards sustainable, environmentallyfriendly production.

- monitoring from from farm level to regional level to national level.

- minimum administrative burden.

- business model for farmers for their performance in area of biodiversity.

- link with market and market rewards.

- policy coherence. 
It is expected that in the new programme period, after 2022, there will be $5 \%$ less budget available for the CAP with a total amount of $€ 365$ billion for the entire EU for the period 2022 - 2028 ${ }^{1}$. This however will still depend on the decisions taken in the Multiannual Financial Framework (MFF) of the EU. The budget for the Netherlands will be approximately $800 \mathrm{mln}$ euros per year. From 2019 onward the Netherlands applies a flat rate: an equal payment for all eligible hectares.

To achieve a greater contribution to the aforementioned goals, the CAP will focus more on monitoring and rewarding concrete results instead of focusing on detailed rules. Also abandoning the 'one size fits all' approach should contribute to a better policy perfomance. Member States will work towards more tailormade approaches at different spatial scales: national, regional and local. Member States are therefore given more freedom to decide on the best way to achieve the objectives and at the same time respond to the specific needs of farmers and the countryside. This is done in order to maximise subsidiarity: the EU only acts when common action is needed and countries will have more decision-making control.They have to account for the policy implementation choices they make in their National Strategic Plans (NSPs).

\section{Process}

To maximise the contribution of the CAP to the objectives a new delivery model has been designed and consists of (a) a proper definition of objectives of policy intervention based on public needs, (b) a logical linkage between objectives and means (measures and resources available in the given contexts) and (c) an evaluation of intervention effects.

\section{Ad a)}

Member States start with a description of the current situation regarding food, agriculture, nature and the countryside, in terms of strengths and weaknesses, opportunities and threats, resulting in a SWOT analysis. Next, as a follow-up to the SWOT, an assessment of needs is carried out, which lists the policy needs at Member State level with respect to the CAP.

\section{Ad b)}

Based on the assessement of needs, Member States draw up a National Strategic Plan (NSP), which describes how the proposed national policy implementation choices will contribute to the general objectives of the CAP, while taking account of the specific situations of the country. Each Member State determines its national strategy and explains how measures and interventions from both pillars will contribute to achieving the objectives. Appropriate interventions, instruments and measures can then be selected. These concern, for example, choices with respect to the enhanced conditionality, the new eco-scheme regulation, and agro-environmental climate schemes as these may be offered via the $2^{\text {nd }}$ pillar.

\section{Ad c)}

To evaluate the results and impacts of the CAP interventions, the CAP proposals provide a monitoring framework. This framework monitors the annual expenditure based on output indicators, the progress towards the targets with result indicators and assesses the performance towards the objectives with impact indicators.

The new CAP will presumably start in 2023 and for the period 2021-2022 a transitional period is planned. In the coming period the new CAP will continue to take shape in an iterative process with the European Commission, the European Parliament, the Member States and the European Council.

\section{Instruments}

The current structure will remain essentially unchanged: the $1^{\text {st }}$ pillar for direct income support, consisting of yearly payments to farmers and market organisation and the $2^{\text {nd }}$ pillar for rural development payments, which consists of investments or multi-annual payments. Also it is proposed that the internal and external convergence of the budget should continue.

For farmland biodiversity and other environmental objectives, the way in which the green architecture is implemented is particularly important. Some important changes for the green architecture for the CAP after 2022 are proposed. In the current situation, the green architecture consists of three parts: cross compliance, greening measures in the $1^{\text {st }}$ pillar and subsidies for agri-environmental measures in the $2^{\text {nd }}$ pillar.

The EC proposes the use of different greening architecture from 2020, with greater scope for flexibility

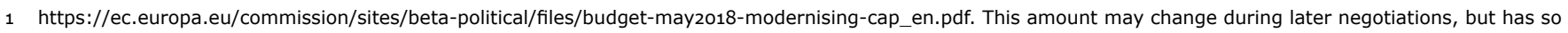
far stayed at its current level, although under the Finish presidency in 2019 a further reduction has been agreed with respect to the total EU budget. 


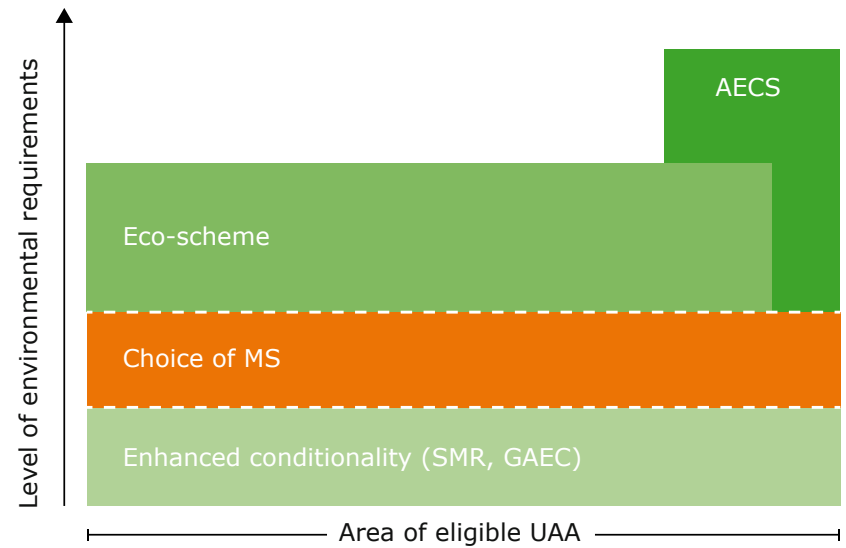

Figure 2. Proposed green architecture of the CAP (UAA= utilised agricultural area; $\mathrm{SMR}=$ Statutory management requirements; GAEC = Good Agricultural and Environmental Conditions; MS= Member States; AECS: agri-environment-climate scheme)

and subsidiarity. In this new greening architecture, the current cross compliance conditions and greening measures are combined into the enhanced conditionality. The enhanced conditionality constitutes the baseline for the environmental conditions. Member States have degrees of freedom to choose specific management requirements, although they should take care that the level of ambition is not jeopardised, relative to that of the current CAP.

A change when compared to the current CAP is that under the new CAP a new instrument has been proposed within the $1^{\text {st }}$ pillar: the eco-scheme. Member States are obliged to introduce at least one eco-scheme to their farmers. They are, however, free to decide on the share of the budget allocated to this scheme (or schemes). They also have freedom regarding to the design and implementation of eco-schemes. The EC proposes that the granting of payments to farmers, with proposed allocation on a per hectare basis, will depend on their performance regarding environmental public services. The implementation must be specified by the Member States in their NSPs.

The $2^{\text {nd }}$ pillar agri-environment-climate measures will continue to exist after 2022 and should be coherent with the enhanced conditionality and the eco-schemes.

Figure 2 shows the proposed greening architecture. The $x$-axis indicates the UAA that is subject to a certain instrument, the $y$-axis indicates the additional environmental conditions.

\subsection{Summary of the draft SWOT for environmental objectives}

To identify relevant issues for the national strategic plan of the CAP, a draft SWOT analysis has been carried out by Berkhout and van Doorn (2019), and an updated version will follow at the end of 2020 or at the start of 2021. For each of the nine CAP objectives the strengths, weaknesses, opportunities and threats are analysed, based on the context indicators of the European Performance, monitoring and evaluation framework and supplemented with national indicators. As the complete SWOT analysis is quite comprehensive, this section focuses on the environmental objectives. First, we discuss the objective on biodiversity, and in Table 2 the objectives on climate and natural resources are also summarised.

\section{Objective f: Preserve landscapes and biodiversity} An overview of the context indicators is given in Table 1; this includes the most recent values and trends for the Netherlands.

Table 1 Context indicators used for the SWOT analysis of the Netherlands for objective $f$

\begin{tabular}{|c|c|c|}
\hline Indicator & value & comment \\
\hline C.19 Farming in Natura 2000 areas & $4.3 \%$ & compared to $10 \%$ on average in EU-27 \\
\hline $\begin{array}{l}\text { C.20 Areas facing natural and other specific } \\
\text { constraints (ANCs) }\end{array}$ & $\begin{array}{l}\text { The regulation of ANCs is not implemented in } \\
\text { the Netherlands }\end{array}$ & \\
\hline $\begin{array}{l}\text { C. } 21 \text { Agricultural land covered with landscape } \\
\text { features }\end{array}$ & $\begin{array}{l}\text { No national data. Estimate based on regional } \\
\text { databases: } 3.5 \%\end{array}$ & $\begin{array}{l}\text { (around EU average), landscape percentages } \\
\text { may differ depending on type }\end{array}$ \\
\hline C.35 Farmland Bird Index & 64 & decreasing trend \\
\hline $\begin{array}{l}\text { C. } 36 \text { Percentage of species and habitats of } \\
\text { Community interest related to agriculture with } \\
\text { stable or increasing trends }\end{array}$ & $3.8 \%$ & smallest share of the EU \\
\hline $\begin{array}{l}\text { National data bumblebees, dragonflies, } \\
\text { butterflies }\end{array}$ & & downward trends \\
\hline
\end{tabular}


Based on the context indicators, we can state that the biodiversity indicators show negative trends and that the share of habitats or species related to agriculture that does not show a negative trend is less than $4 \%$, the smallest share of the EU.

In the SWOT analysis the main threats to biodiversity are identified. Outside agriculture these are: industry, urbanisation, infrastructure, climate change and population density. Threats from agriculture are related to the intensity of production: desiccation, nitrogen emissions/deposition, monocultures, use of plant protection products and disappearance of 'seminatural' areas.

The strengths observed are: the emergence of agricultural cooperatives for agri-environmental management, and a growing consensus that a transition towards nature-based circular agriculture is needed.

As for the other objectives on climate action and natural resources, threats also include ongoing climate change, land use pressure and the polarisation of the societal debate on agriculture and the environment. Innovations towards climate-smart and environmental-friendly farming are mentioned as opportunities, as well as the governmental long-term vision on circular agriculture.

In general it can be stated that, although environmental performance is improving slightly, the biodiversity and the state of many agro-ecosystems and landscape is critical. This also has to do with the fact that biodiversity is not regarded as an integrative part of farm management.

\subsection{Choices for Member States}

The CAP has various instruments that are relevant for supporting biodiversity, of which the enhanced conditionality (formerly cross-compliance and greening measures), the eco-schemes in the $1^{\text {st }}$ pillar, and the agro-environmental climate measures of the $2^{\text {nd }}$ pillar are the key measures. Also subsidies for non-productive investments can be relevant, but these will not be discussed. This section provides an overview of the choices that Member States have, what the options are for biodiversity conservation in farmland, and in what way the enhanced conditionality and the eco-schemes could be implemented.

Table 2 Overview of SWOT analysis of the Netherlands for objectives d, e and f

Objective d: Climate action and sustainable energy production

- public-private collaboration

- knowledge to innovate

- initiatives of value chain partners
Objective e: Support sustainable development and efficient management of natural resources such as water, soil and air.

- efficient production per unit

- some environmental indicators show stable or positive trends

- increase of initiatives for sustainable production in the value chain
Objective f: Preserve landscapes and biodiversity

- diversity of Dutch landscape

- collective nature management

- private initiatives to improve biodiversity (e.g. sustainable dairy chain)

- critical condition of biodiversity/ecosystems/ landscapes

- biodiversity not regarded as an integral part of farm management
- cheap fossil fuels

- high levels of greenhouse gas emissions

- obstructions in policies for circularity
- environmental objectives not achieved (eg nitrogen deposition)

- no integrated approach towards environmental issues

- too little attention to policy and practice in whole agro-ecosystem.

- limitations in market solution due to costs incurred for greening of agricultural production

innovation in farming systems for energy-smart and climate-neutral agriculture
- development of innovative, environmental-friendly farming systems

- governmental vision on circular agriculture offers a perspective for transformative change

- Slight increase of demand for sustainable products
- increasing interest for nature-based farming

- development of reimbursement systems for ecosystem services

- innovative strength of NL/agro-sector
- ongoing climate change: increase of weather exremes such as droughts and floods and need to change land management

- societal debate on agriculture and environment is becoming more polarised polarized
- intensification of land use

- industrialisation, urbanisation, fragmentation of natural areas

- climate change

- incomplete registration of landscape elements 


\begin{tabular}{|c|c|c|c|}
\hline & GAEC & Main objective & Choice for MS \\
\hline \multirow{3}{*}{ Climate } & 1 Maintenance of permanent grassland & $\begin{array}{l}\text { General safeguard against conversion to } \\
\text { other agr. uses to preserve carbon stock }\end{array}$ & Decide on scale of monitoring (share of PG / UAA) \\
\hline & 2 Protection of wetlands and peatlands & Protection of carbon-rich soils & Designation of areas \\
\hline & 3 Ban on stubble burning & Maintenance of Soil Organic Matter (SOM) & \\
\hline \multirow{2}{*}{ Water } & 4 Buffer strips along watercourses & $\begin{array}{l}\text { Protection of river courses against } \\
\text { pollution and run-off }\end{array}$ & $\begin{array}{l}\text { Requirements for width of buffer strip and type of } \\
\text { watercourse }\end{array}$ \\
\hline & 5 Use of farm nutrient tool & Sustainable management of nutrients & Decide on which tool to be used \\
\hline \multirow{3}{*}{ Soil } & $\begin{array}{l}6 \text { Tillage management reducing risk of } \\
\text { soil degradation }\end{array}$ & $\begin{array}{l}\text { Minimal land management to limit } \\
\text { erosion }\end{array}$ & $\begin{array}{l}\text { Specify conditions for soil management and areas } \\
\text { concerned }\end{array}$ \\
\hline & 7 No bare soil during sensitive periods & Soil protection & Specify management requirements \\
\hline & 8 Crop rotation & Maintenance of soil fertility & Specify management requirements \\
\hline \multirow[b]{2}{*}{$\begin{array}{l}\text { Bio- } \\
\text { diversity }\end{array}$} & $\begin{array}{l}9 \text { Minimum share of unfarmed features / } \\
\text { landscape elements }\end{array}$ & Maintenance of non-productive elements & Decide on minimal share of unfarmed features \\
\hline & $\begin{array}{l}\mathbf{1 0} \text { Ban on ploughing / converting } \\
\text { permanent grassland in Natura } 2000 \\
\text { areas }\end{array}$ & Protection of habitats and species & $\begin{array}{l}\text { Decide on areas concerned } \\
\text { (Natura2000 or more) }\end{array}$ \\
\hline
\end{tabular}

\subsubsection{Enhanced conditionality}

It is proposed that the cross compliance and the greening measures from the current CAP should be replaced by a stronger conditionality for environment and climate. Just like the cross compliance, the enhanced conditionality consists of the prevailing laws and regulations (SMRs) and a number of mandatory measures for a "good agricultural and environmental condition (GAECs)" that apply as the baseline for environmental conditions for farmland. Every recipient of CAP payments (payments from the $1^{\text {st }}$ and $2^{\text {nd }}$ pillar) must meet these conditions. The European Commission has proposed a list of 10 GAECs, which are listed in Table 3.

The conditions can be specified per Member State. Article 12 of EC COM 3922018 states: "Member States shall establish at national or regional level the minimum standards to be respected by beneficiaries for good agricultural and environmental condition of the land, taking into account the specific characteristics of the areas concerned, including soil and climate conditions, existing farming systems, land use, crop rotation, agricultural practices and the structure of farms".

GAECs 9 and 10 specifically aim at biodiversity. GAEC 9 sets a minimum threshold on the non-productive area of a farm that offers scope for biodiversity. Member states have to decide upon the percentage to be chosen. The current regulation for ecological focus areas (EFA) uses $5 \%$ of the UAA of the farm ${ }^{2}$. This scheme has been evaluated as not be very effective, since a productionrelated interpretation of EFAs is often chosen by Member States, such as the sowing of catch crops (Doorn 2017, Aliance Environment 2019). From an environmental point of view GAEC 9 is very relevant: in case if a percentage of $5-10 \%$ is chosen for GAEC 9 and and if only nonproductive elements such as field edges and landscape elements are eligible for this share, this GAEC can potentially be of great importance for restoring biodiversity in agricultural areas. From a governance point of view the question is which instrument (enhanced conditionality, eco-schemes or AECS) is most suitable to increase green infrastructure. As permanent grasslands are important for the conservation of endangered meadow birds, GAEC 10 (the ban on converting and ploughing permanent grassland in Natura 2000 areas), is also important for biodiversity.

The other GAECs can support biodiversity as well, such as for example the protection of peat meadow areas (GAEC 2), the development of (herb-rich) buffer strips (GAEC 4), conservation of soil biodiversity by minimal tillage (GAEC 6 ) and more extensive crop rotation (GAEC 8).

For almost all GAECs, Member States can specify specific management requirements depending on the specific national or regional circumstances. An important consideration here is which requirements are seen as setting the environmental baseline, the good agriculture and environmental practice for which no targeted reward

2 Due to several exemptions (e.g. regarding small farms or organic farms) the effective rate is often lower than $5 \%$. 
is needed, and those for which requirements are seen as an environmental performance beyond legal requirements that is rewarded by, for example, the eco-scheme. Where the boundary lies between the environmental baseline following the 'polluter pays' principle and environmental performance following the 'provider gets' principle is not easy to determine unambiguously (Berkhout $\&$ van Doorn 2018). Therefore it has to be considered carefully, especially in terms of effectiveness.

\subsubsection{The eco-schemes}

In addition to the enhanced conditionality, farmland biodiversity can be further supported through the ecoschemes of the 1st pillar. Member States are obliged to implement at least one of these schemes, but farmers can participate on a voluntary basis. It is up to the Member States to determine the share of the budget that will be allocated to the eco-schemes, and the applicable payment rates. The eco-schemes will take the form of an annual payment per eligible hectare. Until now there is no decision on mandatory minimum share of the budget for eco-schemes. The larger the share of the budget that is

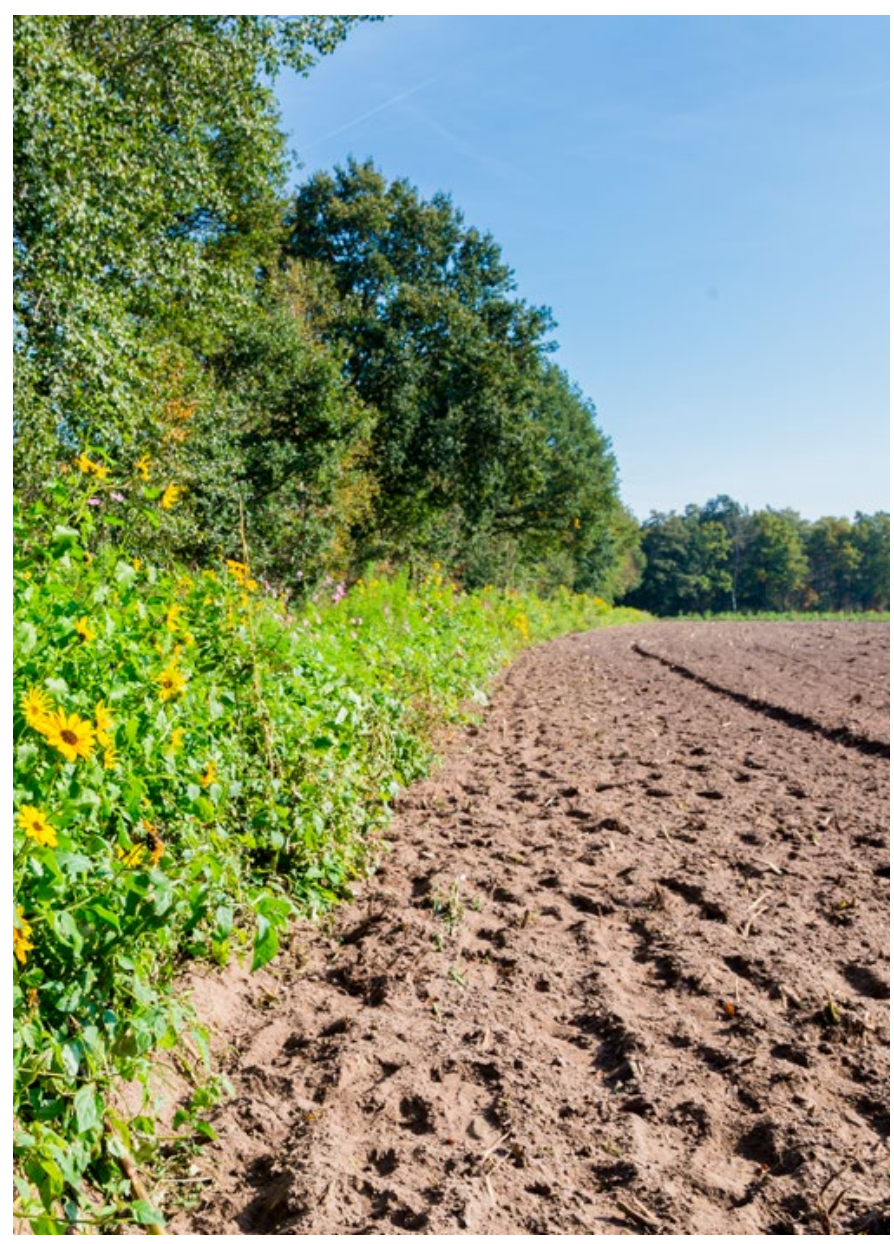

allocated to eco-schemes, the less remains for the "basic income for sustainability".

It is not yet clear how these eco-schemes will be implemented, which will surely vary across Member States. The EC proposal states that: "Member States may decide to establish eco-schemes for agricultural practices such as better management of permanent pasture and landscape elements, and organic farming. These arrangements may also include 'entry level arrangements' which may be a condition for entering into more ambitious rural development commitments." In the latter case, the link between payments and performance may be strengthened beyond what has been applicable in the first and second pillar of the CAP so far: payments will be based on results rather than on compliance with mangement requirements.

With regard to the Netherlands, the budget and content of the eco-schemes that will apply is still unclear. Nevertheless some important remarks can be made: Firstly, concerning the national envelope: the total CAP budget for the Netherlands is expected to become smaller. Implementation of eco-schemes therefore does not mean extra budget, but rather a redistribution of budgets. As noted above, the budget available for the basic payment and the budget for the eco-schemes are interdependent. If in case a large share is spent on the eco-schemes, there will be less available for the basic premium and/or other targeted payments and vice versa. Since payments should relate to efforts made, in general, the higher the payment per hectare, the higher the performance that can be required and expected. Conversely, the higher the payment per hectare, the fewer hectares can be served within the current budget, at least unless no other sources of funding are available.

Secondly, the eco-schemes serve to reward the performance of farmers for climate, soil and biodiversity that go beyond the baseline as established by the enhanced conditionality. In order to make a proper assessment of how the eco-schemes should be deployed, it is important to first properly identify the nature, environment, biodiversity and landscape challenges in rural areas by means of a SWOT analysis. The minimum environmental margins for CAP payments can be determined by the enhanced conditionality.

Basically, there are two options for payments of the eco-schemes: (i) Full or partial compensation for costs incurred/income foregone (including opportunity costs), 
similar to the payments of the agri-environmental measures of the 2nd pillar, or (ii) Fixed top-up payment to the basic income support (based on Member State justification), similar to the current greening payment. The latter option provides flexibility with possibilities to pay more than strictly the cost incurred / income foregone, which allows some scope to further incentivise farmers to join ambitious schemes. So far, no decision on the implementation of one of the options in the Netherlands has been made.

\subsection{Relevant elements of the legislative framework of the CAP}

There are a number of conditions for the legislative framework of the CAP and WTO agreements that should be taken into account when exploring possibilities for implementation of a new instrument such as the DBM. Berkhout et al. (2018) conclude that paying for environmental services is likely to be compatible with the WTO rules, as long as payments are based on the principles as laid down in Annex 2 of the Agreement on Agriculture Domestic support ${ }^{3}$. The most critical condition here is that the payment does not distort trade or stimulate production. As long as payments are exclusively linked to non-productive green measures, this condition is satisfied, and these payments will be declared to be permitted 'Green Box' measures.

In general, targeted payments for environmental objectives are compatible with EU legislation as long as the level of the payment is based on the principle of income foregone and costs incurred, and, where necessary, transaction costs. If payments go beyond this level, it could be argued that they qualify as indirect farm income support, which would be classified as distortive and thus prohibited. Nevertheless, the fixed top-up option for eco-schemes is WTO-proof, as long as managing authorities are able to clearly justify that the payment is compliant with Annex 2 to the WTO Agreement on Agriculture. Annex II of the EC proposal (EC 2018) shows the compatibility of the proposed CAP interventions, such as eco-schemes, with WTO conditions.

The essence of calculating the payments rates is to give a proper reward for the activities undertaken by the farmer and the ensuing costs, while avoiding under and overcompensation. There may be some tension here, as in real life compensation payments will be based on average incurred costs, which by definition implies that some farms have lower costs and some will have higer costs. Ideally, compensation payments should be based on marginal costs, but these are difficult to establish in the first place, and secondly they are also likely to be unstable relative to numbers based on averages. These payments based on marginal numbers would be more in need of revision and updating than average cost-based numbers. Member states are responsible for the implementation of relevant reference levels.

The principles referred to above also imply that if necessary, an amount should be deducted from agrienvironment climate payments, in order to exclude funding of practices required under legislation, or other conditions such as the 'greening' conditions applied to direct payments, as well as practices already funded by the EU through other instruments. In other words: the services rendered in the schemes should be additional to what is already established by the CAP through mandatory standards, enhanced conditionality and GAEC.

Self-evidently, double funding should also be avoided; this means that one activity should be rewarded by a single EU payment, it is not allowed to use different instruments to support a single measure and pay twice for it.

In summary, to explore if and how the DBM can be applied in the CAP, the relevant conditions of the legislative framework and WTO agreements that have to be taken into account are:

1 the instrument should serve (one or more of) the ten CAP objectives and contribute to policy needs as identified in the SWOT analysis;

2 the measure / instrument should fit within the logic of the green architecture of the CAP;

3 no payments for activities below the environmental baseline (enhanced conditionality), support of ecoschems take the form of a payment per eligible hectare and no double funding is allowed;

4 payments for environmental services should be accountable: levels of payments and performance should be underpinned with reliable data on farm practices and cost incurred and income foregone; in principle this is done for individual measures;

5 payments or environmental services should not distort trade or stimulate production and should not go beyond the cost incurred / income foregone (no overcompensation). 


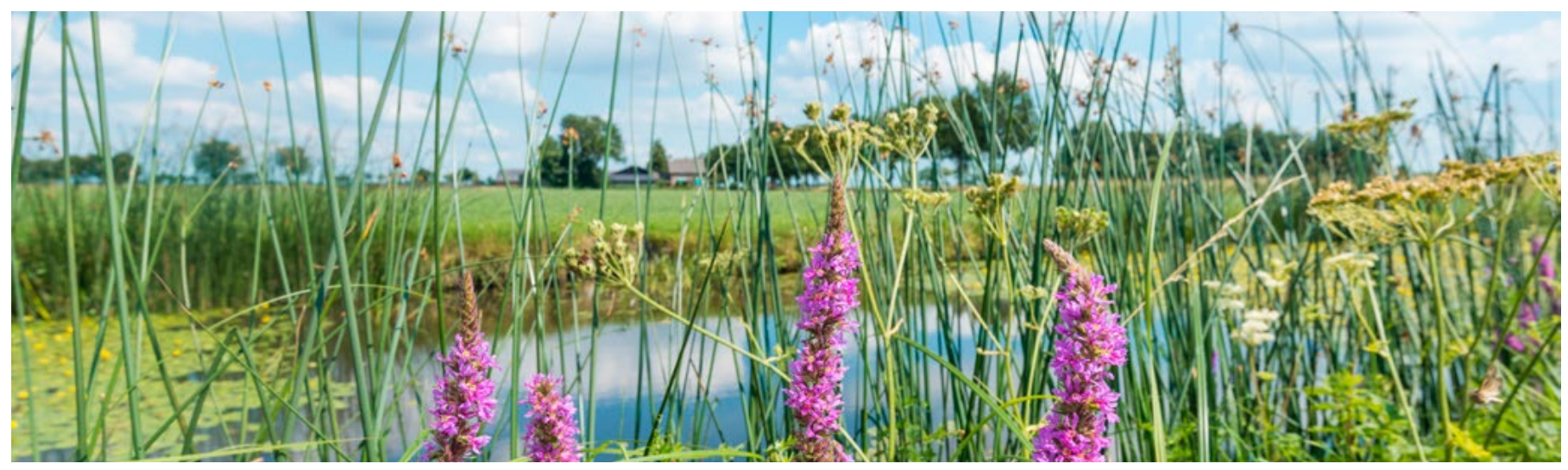

6 Environmental payments should be performancebased, while avoiding 'greenwashing' by preventing options for implementations that do not effectively contribute to the objectives.

\subsection{Current position of the Netherlands}

For the CAP post 2022 the Dutch government intends to direct the CAP budget more towards targeted payments for societal services and less to income support. The CAP is mentioned as an important instrument for many Dutch agri-environmental policy objectives, such as soil and water management, nitrogen issues, climate change mitigation and adaptation, circular agriculture, recovery and conservation of biodiversity. Therefore, an integrated approach for implementation of greening measures in the CAP is especially important.

The Dutch government considers the eco-schemes as a useful instrument and the intention is that these will be implemented in such a way that they are accessible to a wide range of farmers, especially to farmers in the the dairy and arable sector. Currently a point system is being developed for the eco-schemes, where certain activities of farmers are counted as points, and support for ecoschemes is paid based on the points a farmer has earned.

Furthermore, the Dutch government does not intend to implement a strong enhanced conditionality. The conditionality functions as the minimal environmental baseline and the eco-schemes are not meant to reward activities below the minimal baseline. The argument of the Dutch government is that there is a risk that that if the the requirements of the baseline are high in relation to the basic payment, farmers are not able to comply and some will no longer apply for CAP payments. Another argument is that rewarding performance (through the eco-schemes) seems a more effective way to contribute to sustainability than punishing (through the enhanced conditionality). However, on the other hand, the risk of applying a low conditionality is a precedental effect: other member states will also apply low standards for the enhanced conditionality, resulting in a weak environmental baseline for CAP payments

One of the fundamental questions for the Dutch National Strategic Plan is whether CAP payments should contribute to promote the transition towards more sustainable agriculture or the payments should reward farmers whose performance is already in line with the CAP ambitions. The latter option runs the risk of creating a redundancy effect: this is the case when farmers' activities are supported by policies through payments, while these activities would have been realised without payments anyway. Nevertheless, the intention of the Dutch government is to use the CAP budget for both purposes. 


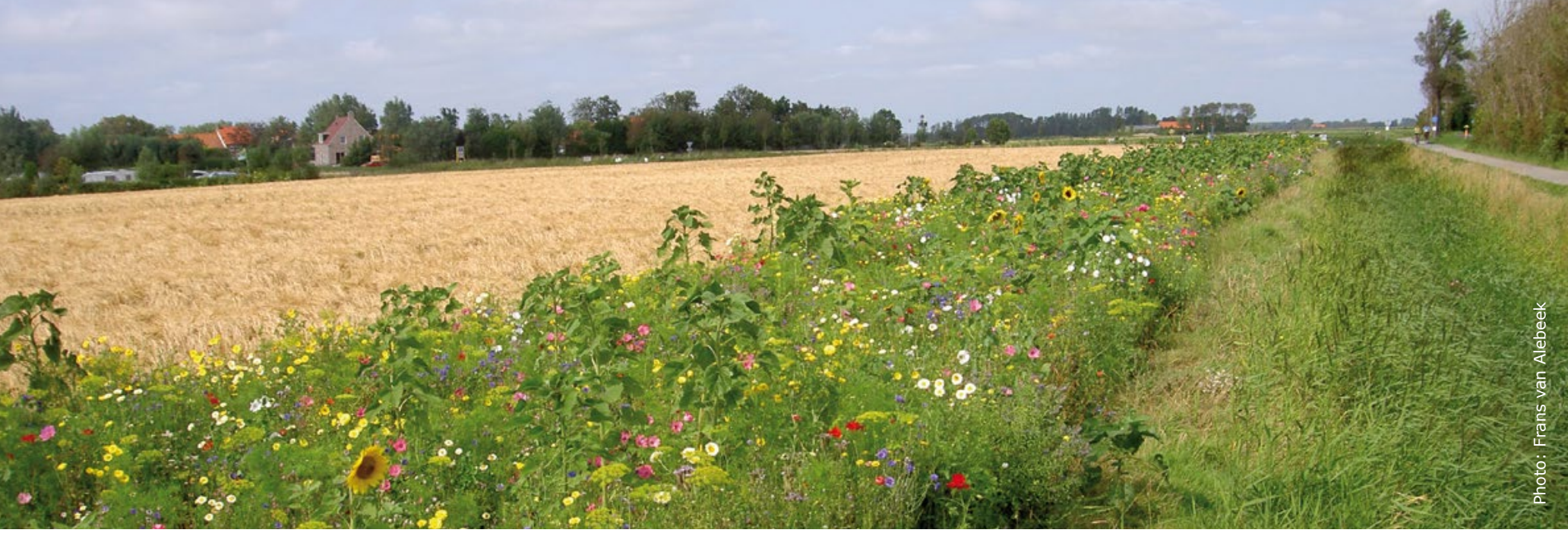

\section{The Dutch Biodiversity Monitor}

\subsection{Background}

\section{Objectives}

To restore and strengthen biodiversity, agriculture can play a major role by enhancing on-farm biodiversity, by strengthening the connectivity between nature areas by providing green infrastructure and by minimising environmental pressures close to the farm and further away. Therefore, it is important that the contribution of farmers to biodiversity conservation can be measured, and subsequently valued and rewarded. When multiple agents in the farm-to-food chain reward the perfomance of farmers, stacked payments for biodiversity and ecosystem services can be made.

The Dutch Biodiversity Monitor (DBM) for Dairy and Arable Farming makes these performances measurable by using Key Performance Indicators (KPIs). The KPIs measure the influence of individual farms on biodiversity on the farm area and beyond. This makes it possible to monitor the performance of farms for biodiversity and the other environmental objectives using a standardised system. The KPIs constitute an integrated set which collectively reflect biodiversity performance. This means a) the biodiversity monitor not only targets biodiversity goals, but also contributes to soil, climate, air and landscape objectives and $b$ ) that KPIs are never applied individually; they have to be used as a set and balance each other out. KPIs do not measure biodiversity directly, but measure key factors which are both crucial for biodiversity and can be influenced directly by farmers. To successfully apply the DBM, monitoring of KPIs should be combined with monitoring of biodiversity, in order to fully understand the relationship between KPIs and biodiversity

Key criteria in the selection of KPIs are integrality and measurability. This means that the set of KPIs can be used to collectively quantify the performance of farmers in an integrated way with the objective of improving biodiversity. This relates to biodiversity on farms and their immediate environment, preservation areas throughout the Netherlands, and biodiversity outside the Netherlands. For example, if fodder is imported from abroad, there may be negative effects on biodiversity in the country of origin. 
It is also important that the KPIs are measurable or can become measurable in the near future. This makes it possible to compare dairy farms with each other and compare farms over an extended period of time. It is important that the performance reflected in the KPIs is ultimately checked against tangible results for biodiversity in and around dairy farms. Furthermore, it is important that the DBM is user-friendly; this can be achieved by restricting the number of KPIs as much as possible in order to ensure an accurate, integrated representation of performance on biodiversity.

\subsection{The Dutch Biodiversity Monitor for dairy farms} Currently the Biodiversity Monitor for the dairy sector consists of 7 KPIs (Table 4) and is tested in the province of
Drenthe by different stakeholders: dairy company FrieslandCampina, Rabobank, the regional government and land owners. The list of KPIs is operationalised and ecological threshold and target values are defined (Doorn 2020).

\subsection{The Dutch Biodiversity Monitor for arable farms}

The DBM for the arable sector is currently under development. A first version of a list of potential KPIs is available, see table 5 . However the monitor and choice for KPIs is still being researched and developed towards a core set of KPIs including threshold and target values and testing on farms.

Table 4 KPIs of the Biodiversity Monitor for the dairy sector

(source: http://biodiversiteitsmonitormelkveehouderij.nl/docs/Biodiversiteitsmonitor_engels.pdf)

\begin{tabular}{|c|c|}
\hline KPI & Definition \\
\hline 1 Percentage of permanent grassland (PG) & Total acreage of permanent grassland/total acreage of farm $* 100 \%$ \\
\hline $\begin{array}{l}2 \text { Percentage of protein produced by own } \\
\text { farm/in farmer's own region }\end{array}$ & $\begin{array}{l}\text { Percentage of protein produced on the farmer's own land/\%N ( } 1-\mathrm{N} \text { in purchased feed/N in total } \\
\text { feed) } * 100 \%\end{array}$ \\
\hline $\begin{array}{l}3 \text { Nitrogen soil surplus ( } \mathrm{kg} \text { of nitrogen per } \\
\text { hectare) }\end{array}$ & $\begin{array}{l}\text { Nitrogen soil surplus per 'cultivation' = nitrogen supply (including fertiliser, recording nitrogen } \\
\text { levels and nitrogen mineralisation) - nitrogen removal (crops) - nitrogen emissions (air) }\end{array}$ \\
\hline 4 Ammonia emissions ( $\mathrm{NH} 3$ ) in $\mathrm{kg}$ per ha & $\begin{array}{l}\text { Ammonia emissions per ha }=\text { (ammonia emissions from the barn }+ \text { manure storage }+ \text { grazing } \\
+ \text { fertilisation using animal manure }+ \text { use of fertiliser }) / \text { total acreage of farm }\end{array}$ \\
\hline $\begin{array}{l}5 \text { Greenhouse gas emissions } \\
\text { (kg CO2-eq per hectare and per kg) }\end{array}$ & $\begin{array}{l}\text { Greenhouse gas emissions - 'to farm gate' (i.e. the entire supply up to and including the dairy } \\
\text { farm) is the sum of } \mathrm{NO} 2, \mathrm{CH} 4, \mathrm{CO} 2\end{array}$ \\
\hline 6 Percentage of herb-rich grassland & Total acreage of herb-rich grassland / total farm acreage $* 100 \%$ \\
\hline $\begin{array}{l}7 \text { Percentage of managed land based on } \\
\text { a management contract (AECS or other } \\
\text { AEM scheme) }\end{array}$ & $\begin{array}{l}\text { Since different elements contribute to biodiversity in different ways, a weighting factor is used } \\
\text { to determine the amount of land used for nature and landscape elements. }\end{array}$ \\
\hline
\end{tabular}

Table 5 First version of list of KPIs of the Biodiversity Monitor for the arable sector (BO-arable farming 2020)

\begin{tabular}{|c|c|}
\hline KPI & Definition \\
\hline 1 Break crop & $\%$ of rest crops / total acreage of the farm \\
\hline 2 Soil organic matter & Kg soil organic matter, calculated based on yearly balance \\
\hline 3 Nitrogen soil surplus & $\mathrm{Kg} \mathrm{N}$-surplus per ha per yr \\
\hline 4 Crop protection products & Environmental pressure of crop protection products \\
\hline 5 Percentage cover crops & \% cover crops / total acreage of the farm \\
\hline 6 Carbon footprint & $\mathrm{Kg} \mathrm{CO} 2$ per $\mathrm{kg}$ product and $\mathrm{Kg} \mathrm{CO} 2$ per hectare \\
\hline 7 Agri-env. management & $\%$ under agri-env management / total acreage of the farm \\
\hline 8 Regional circularity & Number of ha subject to collaboration with neighbours \\
\hline
\end{tabular}


landscapes, it can be assumed that positive scores on these KPIs contribute to objective $f$ (preserve biodiversity and landscapes), but also d (climate action) and e (environmental care). As the idea is to use the DBM to reward biodiversity performance also in the value chain by multiple agents, it can be assumed that when this is put into practice, the monitor will also contribute to objective a (guarantee farmer income).

As for the national implementation, it is important that the objective of the monitor fits logically into the results of the SWOT analysis, the assessment of needs and the National Strategic plan. Currently the assessment of needs and the national strategic plan is work in progress. The draft SWOT analysis of the Netherlands shows that conservation and promotion of biodiversity related to farmland is one of the major issues.

\subsection{Fit into CAP green-blue architecture}

The objective of the instrument should fit within the logic of the green-blue architecture (GBA) of the CAP, i.e. meaning that the instrument should follow the intervention logic of the GBA:

- the enhanced conditionality constitutes the environmental baseline,

- eco-schemes are additional to the enhanced conditionality and are intended to promote environmental practices that go beyond the environmental baseline,

- agri-environment climate payments are the most targeted payments, eg. to promote conservation of specific species in specific areas. In the Netherlands AECS payments are used to support cooperative actions to protect farmland birds in specific areas.

In principle, there are possibilities to use the DBM in all elements of the GBA. We identified four possibilities for its implementation: in the enhanced conditionality, to organise the payments of the eco-schemes, to organise additional payments for agri-environmental schemes and for monitoring and evaluation purposes. Figure 3 shows the possibilities.

\section{Enhanced conditionality}

In the enhanced conditionality there is an option to use the DBM for the implementation of GAEC 5: this GAEC obliges farmers to use a farm sustainability tool, mainly for educative purposes. In this way the farmer gains insight in his biodiversity performance, which can contribute to raising awareness. The focus is on nutrient management, but maybe using (or including) the DBM is also a possibility.

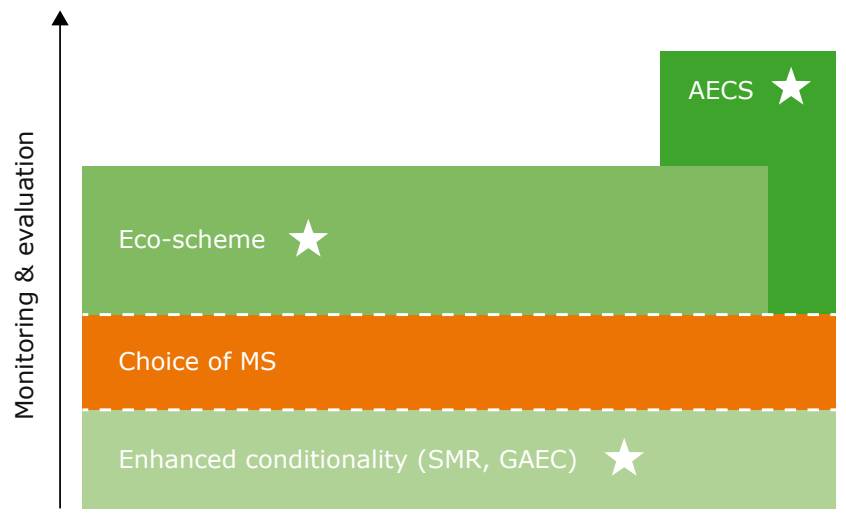

Figure 3 Possibilties for implementation of the biodiversity monitor in the green-blue architecture of the CAP post 2023

\section{Eco-schemes (1st pillar)}

As argued previously, there are basically two options for payments of the eco-schemes: (I) Full or partial compensation for costs incurred/income foregone, similar to the payments of the agri-environmental measures of the $2^{\text {nd }}$ pillar, or (II) Fixed top-up payment to the basic income support, similar to the current greening payment. In principle, the DBM could be used to regulate the payments of the eco-schemes in both options:

I) compensation for costs incurred/income foregone:

g Coupling a total biodiversity score ( Score $_{\mathrm{KPI} 1}+$ Score $_{\mathrm{KPI} 2} \ldots+$ Score $_{\mathrm{KPI}}$ ) to a payment of the ecoscheme. This could be a graduated payment depending on the level of the score.

$\mathrm{h}$ Coupling of score on individual KPIs to a point system, scores on KPIs are translated into points. When a farmer collects sufficient points, he will be rewarded with a graduated payment (the more points, the higher the payment).

II) Fixed top-up payment:

i Farmers that use the DBM and have scores on the KPIs above certain thresholds are considered to be green by definition, and receive an eco-scheme payment.

Options $a$ and $b$ link the scores on KPIs directly to CAP payments. The issue with this kind of structure is the difference in the spatial level of implementation: ecoschemes will be annual payments per eligible hectare where the measure is applied, while KPIs are calculated on farm level and not always translatable to hectares with activities. The question is if and how it is possible to connect /translate these diferent levels. 


\section{Agri-environment climate measures ( $2^{\text {nd }}$ pillar)}

The DBM could also be used to regulate the payments of the agri-environment climate schemes: For example, when farmers collectives make a joint effort to realise regional KPIs. However, the KPI for regional connectivity is still under development and not operational yet.

\section{Monitoring and evaluation}

In principle, the DBM could also have a role in monitoring and evaluation purposes. As both performance-based payments and monitoring and evaluation will become more important elements of the CAP, instruments to monitor the environmental performance of farmers are most welcome. However, it is important to consider carefully how the KPIs relate to the output, result and impact indicators of the Performance Monitoring and Evaluation Framework $\left(\mathrm{PMEF}^{4}\right)$. Figure 4 shows the position of the KPIs in the intervention logic of the CAP, which relates common and specific objectives, measures and indicators. The KPIs can be regarded as the same type of indicator as a result indicator because KPIs do not indicate measures (such as output indicators) and also do not count, e.g. farmland birds (like impact indicators). If the DBM is to be used, it should be taken into account that the indicators of the PMEF are meant to monitor and evaluate the policy, namely the CAP, while KPIs are meant to monitor a farm.

\subsection{No payments for activities below the environmental baseline and no double funding}

If the DBM is used to organise the payments of the eco-schemes, the conditions for environmental payments to farmers are relevant. A first condition is that there will be no payments for activities below the minimal environmental baseline, which is the enhanced conditionality. To explore how the DBM relates to the enhanced conditionality, the table below shows which KPIs are related to which GAECs.

For the eligibility of the payments it is important that the requirements of the DBM go beyond the requirements of the GAECs. For example GAEC 9, this GAEC obliges farmers to allocate $5 \%$ of their utilised agricultural area to unfarmed features. Therefore, if the biodiversity monitor is used in an eco-scheme, the KPI 7 should have a threshold of higher than $5 \%$. Above that percentage the score of the KPI is above the minimal environmental baseline. This is only an issue if an eco-scheme is based on compensation of cost incurred / income foregone.

An important remark here is that the KPIs should be considered as an integrated set and not as individual measures, as the GAECs are. Therefore the joint performance of the set of KPIs cannot actually be compared with individual GAECs.

As for double funding: we see a risk for double funding for KPI 7. The definition of this KPI is the share of the area under agri-environmental management. It is important that a farmer does not receive AES payments under the $2^{\text {nd }}$ pillar for these hectares, as in that case the same activity will be rewarded a second time which implies double funding. It must therefore be ensured that only agri-environment schemes which are not part of the agri-environment-climate measures of the $2^{\text {nd }}$ pillar are included if the DBM is used for an eco-scheme. Another option is to base the payment scheme on a joint index

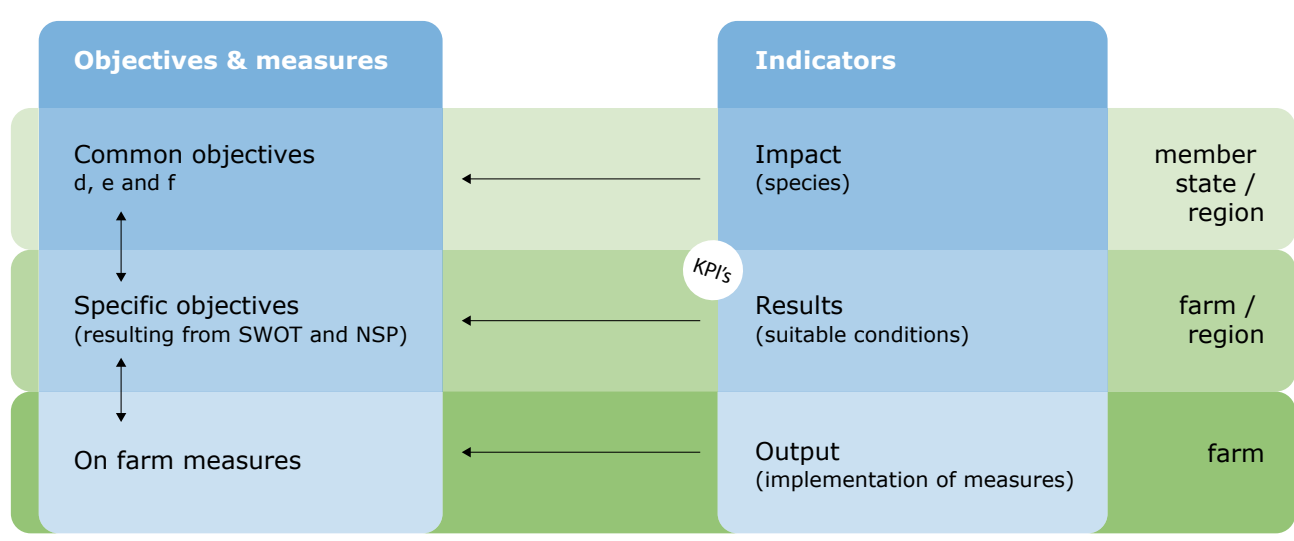

Figure 4 Scheme of the intervention logic of the CAP linking common and specific objectives with on-farm measures and different types of indicators: output, result and impact indicators. The KPIs are depicted in the red square.

4 https://eur-lex.europa.eu/legal-content/EN/TXT/?uri=SWD\%3A2018\%3A301\%3AFIN 


\begin{tabular}{|c|c|c|c|c|c|c|c|}
\hline GAECs & $\begin{array}{l}1 \\
\% \text { PG }\end{array}$ & $\begin{array}{l}2 \\
\text { own } \\
\text { protein }\end{array}$ & $\begin{array}{l}\mathbf{3} \\
\mathbf{N} \text {-surplus }\end{array}$ & $\begin{array}{l}4 \\
\text { NH3 } \\
\text { emissions }\end{array}$ & $\begin{array}{l}5 \\
\text { GHG } \\
\text { emissions }\end{array}$ & $\begin{array}{l}6 \\
\text { \% herb-rich } \\
\text { grassland }\end{array}$ & $\begin{array}{l}7 \\
\text { land under } \\
\text { AEM }\end{array}$ \\
\hline 1 maintenance permanent grassland (PG) & $x$ & & & & & $x$ & \\
\hline \multicolumn{8}{|l|}{2 protection of wetlands } \\
\hline \multicolumn{8}{|l|}{3 ban on stubble burning } \\
\hline \multicolumn{8}{|l|}{4 buffer strips } \\
\hline 5 farm sust. tool & & & $x$ & $x$ & & & \\
\hline \multicolumn{8}{|l|}{6 tillage management } \\
\hline \multicolumn{8}{|l|}{7 no bare soil } \\
\hline \multicolumn{8}{|l|}{8 crop rotation } \\
\hline 9 share of unfarmed features & & & & & & & $x$ \\
\hline 10 ban on ploughing PG in $\mathrm{N} 2 \mathrm{k}$ & $x$ & & & & & $x$ & \\
\hline
\end{tabular}

Legend: overlap / relation of KPIs with GAECs = grey cells

excluding KPI 7, use a remuneration formula which subtracts the payment a farmer receives for GAEC9.

\subsection{Payments should not cause trade distortion and should be accountable}

Within the WTO framework, it is important that the payments should not distort trade or stimulate production. Presumably, this is only the case for KPI 2, as this KPI may distort trade of proteins from elsewhere.

However, a way to avoid this may be to 'translate' this KPI into the share of livestock units (LSU) that can be fed from the farmer's own land. In the latter case the condition can be identified as an indicator restricting the production intensity (e.g. LSU/ha), which has plausibility from an environmental point of view. Here it should be further tested whether such a condition would satisfy the criterion of being 'minimally distorting'. However, here also the complete, integrated set of KPIs should be considered. KPI 1 and 6 will guide the farmer towards a larger share of grassland and in this way balance out KPI 2 .

Another important aspect within the WTO/state aid framework is that payments should be accountable and based on the cost incurred / income foregone. It should be clear which measures are related to KPIs and what the related costs are. Therefore these questions have to be answered:

- what kind of activities does the farmer have to do to score on a KPI?

- to what extent are these activities beyond the environmental baseline?
- what are the costs incurred and the income foregone of these activities?

Answering these questions, which can be done for standardised farms, is necessary to underpin the level of the payments. Therefore coupling KPIs to measures and activities is a crucial element in the implementation of the biodiversity monitor in to the CAP. Therefore an analysis of the relation between KPIs, measures and the costs incurred and income foregone should be carried out and can be based on the work of Beldman et al (2019).

\subsection{Performance based and avoiding green washing}

The ambition of the EC is to strengthen the perfomance of the CAP on environmental goals, therefore the new delivery model provides a solid monitoring and evaluation framework. The Court of Auditors already warned about the risk of green washing (CA, 2017). Therefore it is important to provide a thorough analysis of the KPIs and their expected impact on environmental and biodiversity objectives. An important question to answer is if it is possible to show convincing evidence of the contribution of the KPIs to the issues identified in the SWOT analysis and the needs assessment.

As the relation between KPIs and biodiversity levels is not yet completely understood, there is a risk that it is not possible to completely underpin this with empirical evidence. The fact that there is a positive relationship between the KPIs and biodiversity is clear and well underpinned by scientific literature. The final effect on 
biodiversity is however difficult to predict as it depends very strongly on the location (what biodiversity is present or still present) and the wider landscape context (presence of activities that are not agricultural, but may have a positive or negative influence on local biodiversity). There is also a risk that too low values of KPIs are rewarded. This is especially the case for those KPIs that are not part of the environmental baseline, i.e. which are KPI 2 and KPI 5.

The use of ecological threshold and target values for the KPIs may minimise the risk of green washing. To monitor the perfomance of farmers reliable data are needed, for most KPIs this is the case, although the data availability for KPI 6 and 7 is the weakest.

\subsection{Practicalities}

If the biodiversity monitor is to be implemented as an instrument in the CAP, e.g. to organise the payments of the eco-schemes, there are a number of practical issues that have to be considered. It is beyond the purpose of this memo to examine practical details in depth, but some important issues can already be raised:

- How to guarantee that a positive score on KPIs will indeed contribute to the objectives?

- How to translate KPIs into farming activities and calculate cost incurred / income foregone to underpin the level of payments of the eco-schemes?

- How to streamline the DBM with the point system currently under development by the Dutch government?

- How to include the biodiversity monitor into the riskprotocols of RVO for the checks and controls on compliance and is it possible to check herb-rich grassland?

- How to keep the system of KPIs, monitoring and evaluation simple and minimise the administrative burden? 


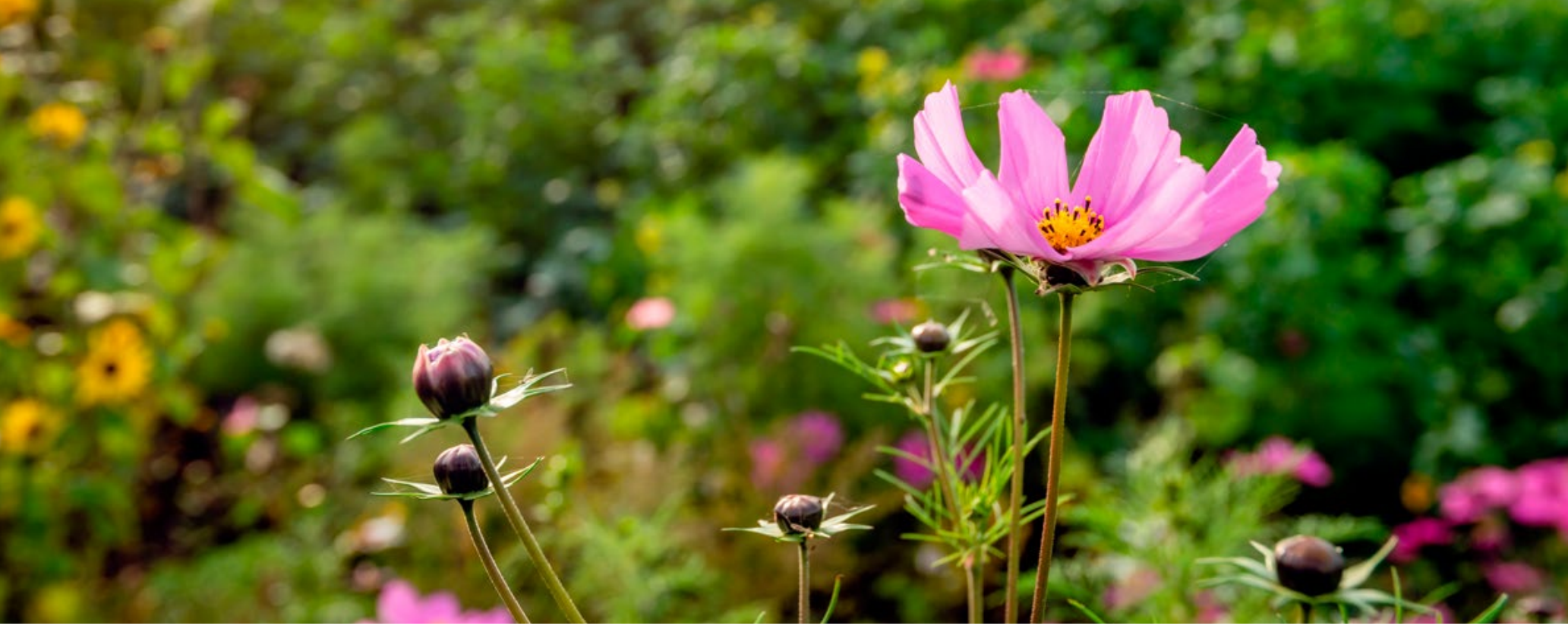

\section{Concluding remarks}

The EC has important green ambitions for the next CAP period, and also the Dutch government aims to target CAP payments at environmental objectives. At the same time policy instruments should be transparent, performance based and contribute to simplification of the policy.

From the above assessment it can concluded that the Dutch Biodiversity Monitor (DBM) fits into these ambitions and has potential to be used in the CAP after 2022. The DBM combines an integrated approach towards biodiversity, environment and climate issues with a relatively simple instrument that allows for performancebased payments. The KPIs can be used for monitoring at farm level with a minimum of administrative burden as most KPIs can be derived from existing administration.

As the DBM integrates indicators for current issues involving biodiversity, environment and climate, corresponding to the CAP objectives f. (preserve biodiversity and landscapes), d. (climate action) and e. (environmental care), it contributes to policy coherence.

Table 7 Summary of pros and coms of applying the Dutch Biodiversity Monitor as a separate instrument in the CAP

\begin{tabular}{|c|c|c|c|}
\hline Aspect & Eco-scheme application & AECS application & Comments \\
\hline Performance level & $\begin{array}{l}\text { Only indicator level beyond the } \\
\text { baseline level should be } \\
\text { recognised as a net contribution }\end{array}$ & $\begin{array}{l}\text { Only indicator level beyond the baseline } \\
\text { level should be recognised as a net } \\
\text { contribution }\end{array}$ & $\begin{array}{l}\text { The baseline level is defined in Enhanced } \\
\text { conditionality }\end{array}$ \\
\hline Double funding & $\begin{array}{l}\text { Pay only for realised net } \\
\text { contribution, apart from } \\
\text { baseline or AECS }\end{array}$ & $\begin{array}{l}\text { Pay only for realised net contribution, } \\
\text { apart from baseline or eco-scheme }\end{array}$ & $\begin{array}{l}\text { The DBM has an interaction effect with } \\
\text { AECS with regard to its its KPI } 7 \text { which } \\
\text { needs careful consideration }\end{array}$ \\
\hline WTO compatibility & $\begin{array}{l}\text { Avoid payments beyond cost- } \\
\text { incurred }\end{array}$ & $\begin{array}{l}\text { Only allows cost-incurred, which } \\
\text { guarantees it is a a green box payment }\end{array}$ & $\begin{array}{l}\text { The DBM may have a potential market } \\
\text { distorting effect with regard to its it KPI 2, } \\
\text { although this effect could be less when } \\
\text { the whole set of KPIs is applied. }\end{array}$ \\
\hline $\begin{array}{l}\text { Data availability } \\
\text { (are data on KPIs } \\
\text { available) }\end{array}$ & Data on most KPIs are available & Data on most KPIs are available & $\begin{array}{l}\text { The DBM has a potential weakness with } \\
\text { regard to the reliability of data }\end{array}$ \\
\hline
\end{tabular}


We conclude that the DBM fits within the logic of the green architecture of the CAP as well as in the new delivery system, with its emphasis on increasing reliance on performance-based schemes, and that it has the potential to be used as an instrument for the eco-schemes.

If the aim is to use the BDM in the context of eco-schemes or as part of the AECS, several pros and cons have been addressed in this study (see Table 7)

\subsection{Options for application and the way forward}

Two options were presented for implememtation of the DBM in the eco-schemes:

A first option is to link the scores on KPIs to a point system which translates ecological performance into payments based on cost incurred and income foregone. A second option is to use the DBM for the eco-schemes by considering farmers that use the DBM and score above certain thresholds, as green by definition and therefore they receive a green top-up.

The second option seems most favourable, at least in the short term, as the first one faces the issue of payments per hectare, while KPIs apply to the farm level, and some of them are hard to quantity as activities per hectare.

In either case it should be safeguarded that there are no payments for activities below enhanced conditionalitiy and no double funding is allowed. Furthermore, payments should not distort trade or stimulate production and should be accountable: levels of payments and performance should be underpinned with reliable data on cost incurred and income foregone and payments should not go beyond that (no overcompensation). These side conditions can be met when:

- Threshold values for KPIs are above the GAEC requirements

- There is no KPI that corresponds with agri-environment schemes of the 2nd pillar

- Calculations linking KPIs with farming activities and cost incurred / income foregone are available to underpin the level of payments of the eco-schemes.

Presumably, this list of side conditions is not complete. A way to explore how things can work in practice is learning by doing in a pilot study. In a pilot the practicalities mentioned in 4.6. can also be explored.

A strength of the DBM is that it relates KPIs to biodiversity results. Another strength is that the indicator is based on a consensus between NGOs and farmer organisations and agri-businesses, which guarantees a broad support among stakeholders. A weakness is that the evidence underpinning the relationship between the KPIs and the impact on biodiversity is difficult to predict as it depends very strongly on the location and wider context in which a multitude of factors eventually determine the state of biodiversity. Therefore, monitoring the relation between KPIs and impact indicators on biodiversity should also be part of the a above-mentioned pilot. 


\begin{tabular}{ll}
\hline AECM & $\begin{array}{l}\text { Agri-environment climate measures (part of 2nd } \\
\text { CAP pillar) }\end{array}$ \\
\hline AECS & $\begin{array}{l}\text { Agri-environment climate scheme (part of 2nd } \\
\text { CAP pillar) }\end{array}$ \\
\hline AEM & Agri-environment measures \\
\hline AKIS & Agricultural Knowledge and Information System \\
\hline CAP & Common Agricultural Policy \\
\hline DBM & Dutch Biodiversity Monitor \\
\hline EC & European Commission \\
\hline EFA & Ecological Focus Area \\
\hline GAEC & Good environmental and agricultural condition \\
\hline
\end{tabular}

\section{List of references}

Alliance Environnement 2019 Evaluation of the impact of the CAP on habitats, landscapes, biodiversity AGRI-20180492 European Commission, DG Agri DOI:

$10.2762 / 818843$

Beldman, A., Polman, N., Kager, H., Doornewaard, G., Greijdanus, A., Prins, H., .Koppenjan, J. (2019).

Meerkosten biodiversiteitsmaatregelen voor melkvee- en akkerbouwbedrijven. (Wageningen Economic Research rapport; No. 2019-105). Wageningen: Wageningen Economic Research.

Berkhout, Petra; Anne van Doorn; Floor Geerling-Eiff; Harold van der Meulen; Gemma Tacken; Gabe Venema; Theo Vogelzang; 2019. De landbouw en het landelijk gebied in Nederland in beeld : Een houtskoolschets van de SWOT voor het GLB Wageningen Economic Research rapport : 2019-058

Berkhout, Petra; Anne van Doorn \& Raymond Schrijver, 2018, Targeted payments for services delivered by farmers: possible approaches Wageningen: Wageningen Economic Research. 33 p. (Wageningen Economic Research report; no. 2018-052)

Cour of Auditors 2017 Special Report n²1/2017: Greening: a more complex income support scheme, not yet environmentally effective Brussels https://op.europa. eu/webpub/eca/special-reports/greening-21-2017/en/

\begin{tabular}{ll}
\hline KPI & Key Performance Indicator \\
\hline MFF & Multi Annual Financial Framework \\
\hline LSU & Livestock Unit \\
\hline NGO & Non-governmental organisation \\
\hline RVO & Netherlands Enterprise Agency \\
\hline SMR & Statutory management requirements \\
\hline SWOT & Strengths Weaknesses Opportunities and Threats \\
\hline UAA & Utilised Agricultural Area \\
\hline WTO & World Trade Organization \\
\hline
\end{tabular}

Doorn, Anne van \& Rob Smidt; 2017 Feiten en cijfers vergroening GLB, Wageningen: Wageningen Environmental Research. 19 p. (Wageningen Environmental Research rapport; no. 2795)

Doorn, Anne van; J.W. Erisman, D. Melman, N. van Eekeren, J.P. Lesschen, T. Visser, H. Blanken, 2020. Drempel- en streefwaarden voor de KPIs van de Biodiversiteitsmonitor melkveehouderij; Normeren vanuit de ecologie. Wageningen, Wageningen Environmental Research, Rapport WENR 2968

EC (2018a). Regulation of the European Parliament and of the Council establishing rules on support for strategic plans to be drawn up by Member States under the Common agricultural policy (CAP Strategic Plans). $\operatorname{COM}(2018) 392$ final. Brussel, 1.6.2018.

Koopmans, Chris; Jan Willem Erisman, Marleen Zanen, Boki Luske; 2017 Biodiverse akkerbouw - Verkenning van indicatoren voor agrobiodiversiteit in de akkerbouw Publicatienummer 2017-023 LbP, Louis Bolk Instituut, Driebergen.

Rli (2019) Advice to the minister of Agriculture, Nature and foodquality: European agricultural policy: working towards circular agriculture. Council for the Environment and Infrastructure 


\section{Colophon}

Title

Author(s)

ISBN number

DOI

Date of publication

Approved by

Reviewer name

Sponsor

Client
Exploring the possibilities for implementation of the Dutch Biodiversity Monitor for dairy and arable farming in the CAP after 2022

Anne van Doorn \& Roel Jongeneel

$978-94-6395-525-6$

https://doi.org/10.18174/530335

$7-9-2020$

Joke de Jong

Berien Elbersen

World Wide Fund For Nature - Netherlands

World Wide Fund For Nature - Netherlands

\section{Wageningen Environmental Research}

P.O. Box 47

NL-6700 AA Wageningen

Tel: +31(0)317 480700

Corresponding author: anne.vandoorn@wur.nl

Internet: wur.nl/nl/onderzoek-resultaten/onderzoeksinstituten/environmental-research.htm

(c) Wageningen Environmental Research, institute within the legal entity Stichting Wageningen Research All rights reserved. No part of this publication may be reproduced, stored in a retrieval system of any nature, or transmitted, in any form or by any means, electronic, mechanical, photocopying, recording or otherwise, without the prior permission of the publisher. The publisher does not accept any liability for inaccuracies in this report. 